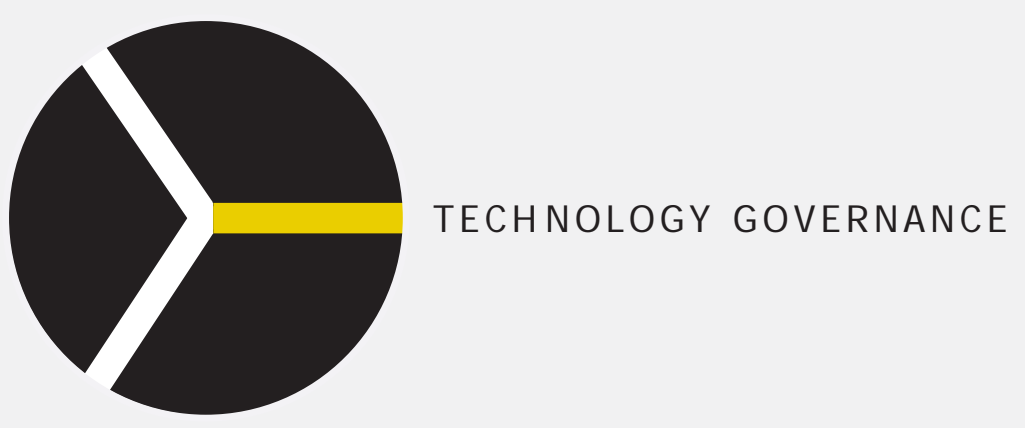

Working Papers in Technology Governance and Economic Dynamics no. 20

THE OTHER CANON FOUNDATION, NORWAY

TALLINN UNIVERSITY OF TECHNOLOGY, TALLINN

\title{
Technological revolutions and techno-economic paradigms
}

Carlota Perez

January 2009

\footnotetext{
1 Technological University of Tallinn, Estonia and Universitites of Cambridge and Sussex, U.K. www.carlotaperez.org
} 


\begin{abstract}
This paper locates the notion of technological revolutions in the NeoSchumpeterian effort to understand innovation and to identify the regularities, continuities and discontinuities in the process of innovation. It looks at the micro- and meso-foundations of the patterns observed in the evolution of technical change and the interrelations with the context that shape the rhythm and direction of innovation. On this basis, it defines technological revolutions, examines their structure and the role that they play in rejuvenating the whole economy through the application of the accompanying techno-economic paradigm. This over-arching meta-paradigm or shared best practice 'common sense' is in turn defined and analysed in its components and its impact, including the influence it exercises on institutional and social change.
\end{abstract}

\title{
Contents
}

Innovation as the dynamic space for the study of technical change 3

The regularities of technical change: innovation trajectories 4

$\begin{array}{ll}\text { New technology systems and their interactions } & 6\end{array}$

$\begin{array}{ll}\text { Technological revolutions and techno-economic paradigms } & 8\end{array}$

$\begin{array}{ll}\text { The structure of technological revolutions } & 10\end{array}$

The emergence of a techno-economic paradigm 13

$\begin{array}{ll}\text { The changes in the cost structure } & 15\end{array}$

$\begin{array}{ll}\text { The perception of opportunity spaces } & 16\end{array}$

$\begin{array}{ll}\text { New organisational models } & 16\end{array}$

Diffusion, resistance and assimilation of successive techno-economic $\begin{array}{ll}\text { paradigms } & 19\end{array}$

Putting it together: Regularities, continuities and discontinuities in $\begin{array}{ll}\text { technical change } & 20\end{array}$

$\begin{array}{ll}\text { References } & 22\end{array}$ 
The growing impact of the Information Revolution and the visibly increasing importance of innovation and entrepreneurship has resulted in a resurging interest in Schumpeterian ideas. Brad De Long suggested in his review of McCraw's biography of Schumpeter that the late 20th and early $21^{\text {st }}$ Century should be as much a Schumpeterian reign as the mid 20th Century was Keynesian. ${ }^{2}$

Indeed, Schumpeter is among the few modern economists to put technical change and entrepreneurship at the root of economic growth. ${ }^{3}$ Yet, strangely enough, he saw technology as exogenous and -together with institutions and social organisations- "outside the domain of economic theory" ${ }^{4}$. His focus was the entrepreneur and his goal was to explain the role of innovation in economic growth and on the cyclicality of the system.

It is the Neo-Schumpeterians who have endeavoured to analyse technical change and innovation as such, with their regularities and evolution; who have delved into the characteristics and dynamics of innovation, from individual technical changes through clusters and systems to technological revolutions. This task has been performed by looking at technology, engineering and business organisation from the perspective of the economist and the social scientist, identifying the common features in the processes of evolution, in the interrelations and in the breakthroughs that occur in the most diverse technical areas. These regularities then inform an understanding of the relationship between technical and organisational change, between these and economic performance as well as the mutual relationships between technology, the economy and the institutional context.

This paper will concentrate on technological revolutions and techno-economic paradigms, their definition, the causal mechanisms that bring them about, their impact on the economy and institutions and their relevance for economic analysis. Yet, since these macro phenomena are deeply rooted in the micro-foundations of technical change, the following section will refer to some of the basic theoretical advances made at the micro and meso levels.

\section{Innovation as the dynamic space for the study of technical change}

Schumpeter strongly distinguished innovation, seen as the commercial introduction of a new product or a "new combination", from invention,

\footnotetext{
2 De Long (2007)

3 Schumpeter (1911 and 1939) In earlier times from Serra (1613) in Renaissance Italy to Friedrich List (1841) in pre-unified Germany, the importance of technology and skills in economic growth was recognised as obvious. See Reinert (2007)

4 Schumpeter (1911:1926:1961) p.11
} 
which belongs to the realm of science and technology. ${ }^{5}$ Indeed, the space of the technologically possible is much greater than that of the economically profitable and socially acceptable. It is with profit in mind that entrepreneurs and managers are constantly turning inventions into innovations; technical possibilities and discoveries into economic realities. In turn, through their investment and funding decisions, they can also steer the research effort in particular directions.

Those decision processes are not random. They are shaped by the context, including relative prices, regulatory and other institutional factors and obviously, their perceived market potential. They are also path-dependent, because market potential often depends on what the market has already accepted and because the incorporation of technical change requires the coming together of several pre-existing explicit and tacit knowledge bases and various sources of practical experience.

Thus, the meaningful space where technical change needs to be studied is that of innovation, at the convergence of technology, the economy and the socio-institutional context. That space is essentially dynamic and, in it, the basic concept is that of a trajectory or paradigm, ${ }^{6}$ which represents the rhythm and the direction of change in a given technology.

\section{The regularities of technical change: innovation trajectories}

Radical individual innovations are introduced in a relatively primitive version and, once market acceptance is achieved, they are subjected to a series of incremental innovations following the changing rhythm of a logistic curve (See figure 1). Changes occur slowly at first, while producers, designers, distributors and consumers engage in feedback learning processes; rapidly and intensively once a dominant design ${ }^{7}$ is established in the market and slowly once again when maturity is reached and Wolf's ${ }^{8}$ law of diminishing returns to investment in innovation sets in.

\footnotetext{
5 Schumpeter (1911:1926:1961) pp. 132-6. See a discussion in Nelson and Winter (1982) pp. $263-6$

6 Dosi (1982)

7 Arthur (1988)

8 Wolf (1912)
} 
Figure 1.The trajectory of an individual technology

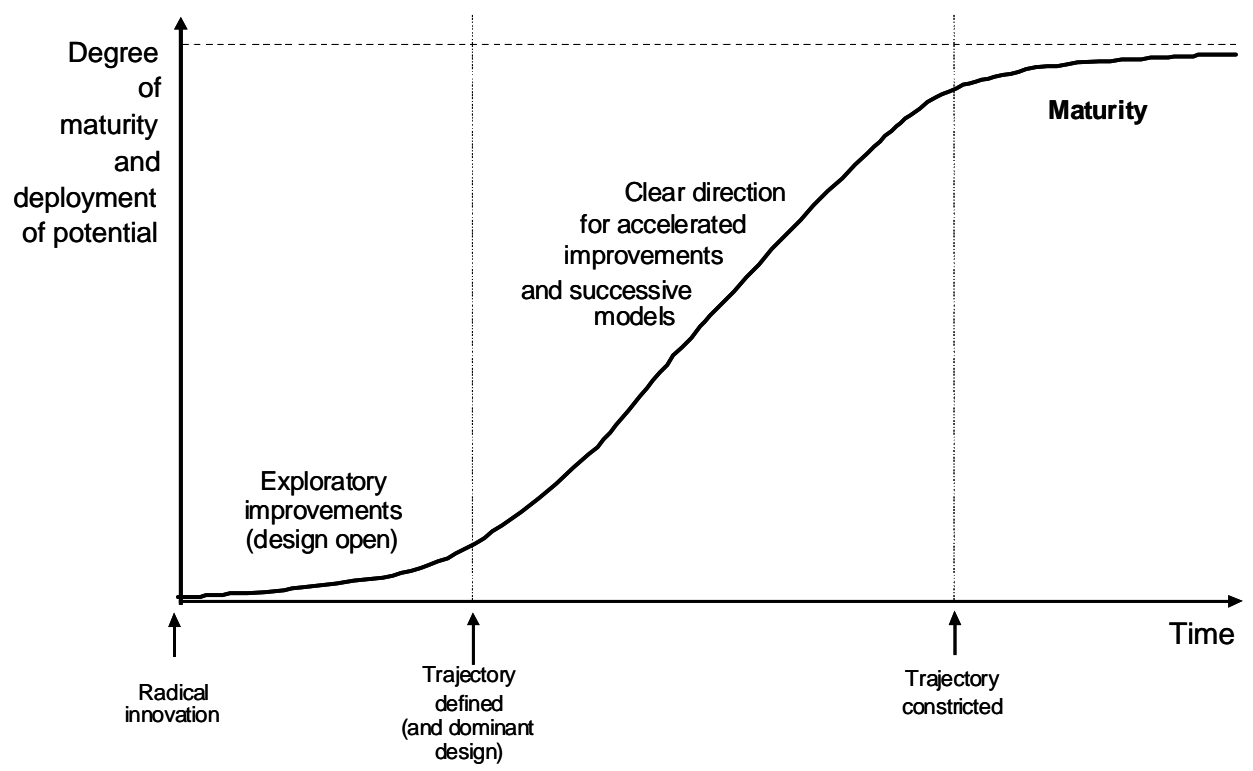

Source: Based on Nelson and Winter, Dosi, Metcalfe, Wolf, Utterback and Abernathy, Arthur, etc.

But, together with rhythm, a trajectory also involves directionality within a possibility space. That is what Dosi emphasized when, with the Kuhnian parallel in mind, ${ }^{9}$ he introduced the term technical paradigm to represent the tacit agreement of the agents involved as to what is a valid search direction and what will be considered an improvement or a superior version of a product, service or technology. A paradigm is then a collectively shared logic at the convergence of technological potential, relative costs, market acceptance, functional coherence and other factors. Microprocessors (and the products based on them) are expected to become faster, smaller, more powerful, more versatile, relatively cheaper and so on. By contrast, automobiles and airplanes in the 1950s and 1960s were supposed to become bigger and bigger and, though they were also expected to be faster, versatility was not among the goals.

Thus the notions of trajectory or paradigm highlight the importance of incremental innovations in the growth path following each radical innovation. Though it is true that major innovations have a central role in determining new investment and economic growth, expansion depends on incremental innovation $^{10}$. The numerous minor innovations in product enhancement and

\footnotetext{
9 Kuhn (1962:1970) on scientific paradigms

10 Enos (1962)
} 
process improvement that follow the introduction of any new product have an important impact on productivity increases and market growth. It has been shown that, some time after the take-off, both the number and the importance of incremental process innovations tend to overtake product changes. ${ }^{11}$ As production volume and productivity become crucial for market expansion, process innovations drive most of the scaling-up investment.

As will be discussed below, what holds for individual technologies in terms of regularities in the dynamism and direction of technical change occurs also at the meso level, in relation to the evolution of all the products in an industry and to that of whole sets of interrelated industries.

Of course these notions and observations represent only the general patterns that characterise the standard dynamics of technical change and there are multiple deviations and exceptions in specific cases.

\section{New technology systems and their interactions}

The emergence of individual innovations is not random. Technologies interconnect and tend to appear in the neighbourhood of other innovations. ${ }^{12}$ Neither does their evolution take place in isolation. Innovation is a collective process that increasingly involves other agents of change: suppliers, distributors and many others, including consumers. The Schumpeterian clusters are the result of techno-economic and social interactions between producers and users within complex dynamic networks. Furthermore, major innovations are inductors of further innovations; they demand complementary ones upstream and downstream and facilitate similar ones, including competing alternatives.

A sufficiently radical innovation such as, for example, television stimulated the emergence of the industries that manufacture receiving and broadcasting equipment and of multiple specialized supplier industries. TV spurred the transformation of the producing and advertising industries as well as the film, music and other creative sectors, plus new maintenance and distribution activities and so on.

This dynamic interrelatedness has led to the notion of a technology system studied by Freeman ${ }^{13}$ to describe how the Schumpeterian clusters are formed and evolve. At this meso level of analysis, it is found that the

\footnotetext{
11 Utterback and Abernathy (1975)

12 Schumpeter (1939) p. 167

13 Freeman (1992) p. 81 and (1994)
} 
process of diffusion also follows a logistic shape (as figure 1). The incremental innovations along the trajectory, rather than simple improvements are successive new products, services and even whole industries, building upon the innovative space inaugurated by the initial radical innovation and widened by the followers.

Each new technology system not only modifies the business space but also the institutional context and even the culture (as disposable plastics did in the past and Internet does now). New rules and regulations are likely to be required, as well as specialized training and other institutional facilitators (sometimes replacing the established ones). These have in turn strong feedback shaping effects upon the technologies.

Maturity will be reached when the innovative possibilities of the whole system begin to wane and the corresponding markets to saturate. Thus, individual technologies are not introduced in isolation. They enter into a changing context that strongly influences their potential and is already shaped by the previous innovations in the system.

A new product appearing in the early phase of a new system has a more dynamic market life ahead than one introduced at its maturity phase. This happens for two main reasons. One is the exhaustion of the opportunity space of that particular system, so that the last innovations are likely to be very minor. For example, the long series of home electrical appliances in the early $20^{\text {th }}$ Century began with the refrigerator and the washing machine and petered out with the electric can-opener and the electric carving knife. The other reason for decreasing market dynamism is the intense learning that occurs within the system and the externalities that result from it. These tend to reduce the time to market and to ease user acceptance thus shortening the product life-cycle and cutting down the time for profitability. For instance, it took 24 years, from 1954, to incorporate air conditioning as an improvement in $90 \%$ of the automobiles produced in the US, whereas radial tyres, introduced in 1970 , took less than 8 years to reach $90 \%$ of the market. $^{14}$

The complex and changing network of interactions and cooperation among the many agents that contribute to innovations -researchers, engineers, suppliers, producers, users and institutions- as a technology system evolves has been conceptualized as a national system of innovation ${ }^{15}$ evoking Friedrich List's national system of political economy ${ }^{16}$. This has natural-

\footnotetext{
14 Cited by Grübler (1990) p. 155

15 Freeman (1987 and 1995), Lundvall (1988)

16 List (1841)
} 
ly led other researchers to the study of regional and sectoral systems of innovation. ${ }^{17}$ The interrelatedness of technologies and of the knowledge and experience bases that underlie their development, together with the infrastructures and service networks that complement them and the multiple learning processes that accompany them, provide externalities for all participants and advantages for the society in which they are embedded.

\section{Technological revolutions and techno-economic paradigms}

Just as individual innovations are interconnected in technology systems, these are in turn interconnected in technological revolutions. Thus, on a first approximation a technological revolution (TR) can be defined as a set of interrelated radical breakthroughs, forming a major constellation of interdependent technologies; a cluster of clusters or a system of systems.

The current information technology revolution, for example, opened a first technology system around microprocessors (and other integrated semi-conductors), their specialized suppliers and their initial uses in calculators, games, civil and military miniaturizing and digitalizing of control instruments and others. After that there was an overlapping sequence of minicomputers and personal computers, software, telecoms and Internet that have each opened new systems trajectories, while being strongly inter-related and inter-dependent. As they appeared, these systems interconnected and continued expanding together with intense feedback loops in both technologies and markets.

A similar stylized description can be made of each of the previous constellations.

Five such meta-systems can be identified since the initial "Industrial Revolution" in England. Each can be seen as inaugurated by an important technological breakthrough acting as the big-bang that opens a new universe of opportunity for profitable innovation. Such was the case of the Intel microprocessor, or computer on a chip, initiating the information revolution. Table 1 indicates the five revolutions, their corresponding big-bangs and the core country where the revolution originally takes shape and from which it spreads across the world (sometimes even concentrated in a particular region: Manchester was as much the cradle and the symbol of the Age of Steam as Silicon Valley has been for the microelectronics revolution)

17 Malerba (2002); Arocena and Sutz (2000); Howells (1999) 
Table 1. Five successive technological revolutions, 1770 s to 2000 s

\begin{tabular}{|l|l|l|l|l|}
\hline $\begin{array}{l}\text { Technologica } \\
\text { Irevolution }\end{array}$ & $\begin{array}{l}\text { Popular name for the } \\
\text { period }\end{array}$ & \multicolumn{1}{|c|}{ Core country or countries } & Big-bang initiating the revolution & Year \\
\hline FIRST & $\begin{array}{l}\text { The 'Industrial } \\
\text { Revolution' }\end{array}$ & Britain & Arkwright's mill opens in Cromford & 1771 \\
\hline SECOND & $\begin{array}{l}\text { Age of Steam and } \\
\text { Railways }\end{array}$ & $\begin{array}{l}\text { Britain (spreading to Continent } \\
\text { and USA) }\end{array}$ & $\begin{array}{l}\text { Test of the 'Rocket' steam engine } \\
\text { for the Liverpool -Manchester } \\
\text { railway }\end{array}$ & 1829 \\
\hline THIRD & $\begin{array}{l}\text { Age of Steel, } \\
\text { Electricity and Heavy } \\
\text { Engineering }\end{array}$ & $\begin{array}{l}\text { USA and Germany forging } \\
\text { ahead and overtaking Britain }\end{array}$ & $\begin{array}{l}\text { The Camegie Bessemer steel } \\
\text { plant opens in Pittsburgh, } \\
\text { Pennsylvania }\end{array}$ & 1875 \\
\hline FOURTH & $\begin{array}{l}\text { Age of Oil, the } \\
\text { Automobile and Mass } \\
\text { Production }\end{array}$ & $\begin{array}{l}\text { USA (with Germany at first } \\
\text { vying for world leadership), } \\
\text { later spreading to Europe }\end{array}$ & $\begin{array}{l}\text { First Model -T comes out of the } \\
\text { Ford plant in Detroit, Michigan }\end{array}$ & 1908 \\
\hline FIFTH & $\begin{array}{l}\text { Age of Information } \\
\text { and } \\
\text { Telecommunications }\end{array}$ & $\begin{array}{l}\text { USA(spreading to Europe and } \\
\text { Asia) }\end{array}$ & $\begin{array}{l}\text { The Intel microprocessor is } \\
\text { announced in Santa Clara, } \\
\text { Califomia }\end{array}$ & 1971 \\
\hline
\end{tabular}

Source: Perez (2002)

What distinguishes a TR from a random collection of technology systems and justifies conceptualizing it as a revolution are two basic features.

1. The strong interconnectedness and interdependence of the participating systems in their technologies and markets.

2. The capacity to transform profoundly the rest of the economy (and eventually society).

The first is the most visible and defines what is popularly understood as "the revolution"; but it is the second that makes it really warrant the term. That capacity to transform other industries and activities results from the influence of its associated techno-economic paradigm $^{18}$, a best practice model for the most effective use of the new technologies within and beyond the new industries. The new industries of the revolution expand to become the engines of growth, for a long period while the techno-economic paradigm drives a vast reorganisation and a widespread rise in productivity across the economy.

Thus, a technological revolution can more generally be defined as a major upheaval of the wealth-creating potential of the economy, opening a vast innovation opportunity space and providing a new set of associated generic technologies, infrastructures and organisational principles that can significantly increase the efficiency and effectiveness of all industries and activities.

18 The term was introduced by Perez (1984) -replacing the previous (1983) technological style - in order to connect with Dosi's (1982) concept of technical paradigms 
The processes of diffusion of each technological revolution and its technoeconomic paradigm -together with their assimilation by the economy and society as well as the resulting increases in productivity and expansionconstitute successive great surges of development. ${ }^{19}$

It should be noted that this concept represents a break with both Kondratiev's and Schumpeter's notion of long waves. ${ }^{20}$ For them, the focus is on the upswings and downswings in economic growth. Although Schumpeter clearly ascribes such waves to technological revolutions while Kondratiev does not commit himself to any particular causal factor, they are both trying to explain long-term variations in GDP and other economic aggregates. The author has suggested focusing instead on explaining the process of diffusion of each technological revolution and on its transformative effects on all aspects of the economy and society, including among them the impact on rhythms of economic growth. This has resulted on different dating of the surges (as opposed to those of the traditional long waves) and on identifying a different set of regularities in the patterns of diffusion which are the object of the discussion that follows. ${ }^{21}$

\section{The structure of technological revolutions}

The interconnection of the technologies of a revolution takes place at several levels.

a. They stem from the same areas of knowledge in science and technology and use similar engineering principles.

b. They require similar skills for design and operation -quite often new ones.

c. They stimulate the upstream development of a common network of suppliers of inputs and services as well as interdependent distribution outlets.

d. Their dynamism is mutually driven through very strong interlinkages, often being the main market for each other (the more growth and innovation there is in computers, the more growth and innovation there will be in semiconductors and vice versa).

e. Their diffusion generates coherent patterns of consumption and use

\footnotetext{
19 Perez (2002) pp. 20-21

20 Schumpeter (1939), Kondratiev (1935). For a selection of the main authors (both from evolutionary economics and from other schools of thought) see Freeman ed. (1996) and for the more statistical treatment of the same Louca and Reijnders eds. (1999)

21 For a critique of the use of the term long waves in economic growth and an explanation of the switch to using great surges of development see Perez (2002), Ch. 6. See also Perez (2007) pp. 783-6
} 
so that the learning in one system facilitates the learning in the next and the installation of conditions for the use of one set of products becomes an externality for the next (once electricity comes to the home for lighting and refrigeration, it facilitates the adoption of radios and vacuum cleaners).

A technological revolution basically introduces whole new sections in the input output table which gradually become the most dynamic (and end up modifying the rest).

In terms of structure, each revolution includes a significant number of interrelated new products and production technologies, giving rise to important new industries. Among them there tends to be a core all-pervasive low-cost input, often a source of energy, sometimes a crucial material, plus one or more new infrastructures. The latter usually change the frontier and conditions of transportation networks -for products, people, energy and information- extending their reach and increasing their speed and reliability while drastically reducing their cost.

Table 2 indicates the main industries and infrastructures of each of the five technological revolutions that took place since the "Industrial Revolution" at the end of the 18th Century 
Table 2. Five Technological Revolutions: Main industries and infrastructures

\begin{tabular}{|c|c|c|}
\hline $\begin{array}{l}\text { Technological } \\
\text { revolution }\end{array}$ & $\begin{array}{l}\text { 2. New technologies and } \\
\text { new or redefined industries }\end{array}$ & $\begin{array}{l}\text { 3. New or } \\
\text { redefined infrastructures }\end{array}$ \\
\hline $\begin{array}{l}\text { FIRST: } \\
\text { The 'Industrial } \\
\text { Revolution' }\end{array}$ & $\begin{array}{l}\text { Mechanized cotton industry } \\
\text { Wrought iron } \\
\text { Machinery }\end{array}$ & $\begin{array}{l}\text { Canals and waterways } \\
\text { Turnpike roads } \\
\text { Water power (highly improved water } \\
\text { wheels) }\end{array}$ \\
\hline $\begin{array}{l}\text { SECOND: } \\
\text { Age of Steam and } \\
\text { Railways }\end{array}$ & $\begin{array}{l}\text { Steam engines and machinery } \\
\text { (made in iron; fueled by coal) } \\
\text { Iron and coal mining (now playing } \\
\text { a central role in growth)* } \\
\text { Railway construction } \\
\text { Rolling stock production } \\
\text { Steam power for many } \\
\text { industries(including textiles) }\end{array}$ & $\begin{array}{l}\text { Railways (Use of steam engine) } \\
\text { Universal postal service } \\
\text { Telegraph (mainly nationally along } \\
\text { railway lines) } \\
\text { Great ports, great depots and world- } \\
\text { wide sailing ships } \\
\text { City gas }\end{array}$ \\
\hline $\begin{array}{l}\text { THIRD: } \\
\text { Age of Steel, } \\
\text { Electricity and } \\
\text { Heavy Engineering }\end{array}$ & $\begin{array}{l}\text { Cheap steel (especially Bessemer) } \\
\text { Full development of steam engine } \\
\text { for steel ships } \\
\text { Heavy chemistry and civil engi- } \\
\text { neering } \\
\text { Electrical equipment industry } \\
\text { Copper and cables } \\
\text { Canned and bottled food } \\
\text { Paper and packaging }\end{array}$ & $\begin{array}{l}\text { Worldwide shipping in rapid steel } \\
\text { steamships (use of Suez Canal) } \\
\text { Transcontinental railways (use of } \\
\text { cheap steel rails and bolts in stan- } \\
\text { dard sizes). } \\
\text { Great bridges and tunnels } \\
\text { Worldwide Telegraph } \\
\text { Telephone (mainly nationally) } \\
\text { Electrical networks (for illumination } \\
\text { and industrial use) }\end{array}$ \\
\hline $\begin{array}{l}\text { FOURTH: } \\
\text { Age of Oil, the } \\
\text { Automobile and } \\
\text { Mass Production }\end{array}$ & $\begin{array}{l}\text { Mass-produced automobiles } \\
\text { Cheap oil and oil fuels } \\
\text { Petrochemicals (synthetics) } \\
\text { Internal combustion engine for } \\
\text { automobiles, transport, tractors, } \\
\text { airplanes, war tanks and electricity } \\
\text { Home electrical appliances } \\
\text { Refrigerated and frozen foods }\end{array}$ & $\begin{array}{l}\text { Networks of roads, highways, ports } \\
\text { and airports } \\
\text { Networks of oil ducts } \\
\text { Universal electricity (industry and } \\
\text { homes) } \\
\text { Worldwide analog telecommunica- } \\
\text { tions (telephone, telex and cable- } \\
\text { gram) wire and wireless }\end{array}$ \\
\hline $\begin{array}{l}\text { FIFTH: } \\
\text { Age of Information } \\
\text { and Telecommuni- } \\
\text { cations }\end{array}$ & $\begin{array}{l}\text { The information revolution: } \\
\text { Cheap microelectronics. } \\
\text { Computers, software } \\
\text { Telecommunications } \\
\text { Control instruments } \\
\text { Computer-aided biotechnology and } \\
\text { new materials }\end{array}$ & $\begin{array}{l}\text { World digital telecommunications } \\
\text { (cable, fiber optics, radio and satel- } \\
\text { lite) } \\
\text { Internet/ Electronic mail and other } \\
\text { e-services } \\
\text { Multiple source, flexible use, elec- } \\
\text { tricity networks } \\
\text { High-speed multi-modal physical } \\
\text { transport links (by land, air and } \\
\text { water) }\end{array}$ \\
\hline
\end{tabular}

Note:* These traditional industries acquire a new role and a new dynamism when serving as the material and the fuel of the world of railways and machinery

Source: Based on Perez (2002) p. 14 
From the point of view of the role they play in driving change, the core industries of each revolution can be ranged into three main categories: ${ }^{22}$

1. The motive branches which produce the cheap inputs with pervasive applicability: Semiconductors today, oil and plastics in the previous surge, cheap steel in the third, coal in the second and water wheels in the first. ${ }^{23}$

2. The carrier branches which are the most visible and active users of the inputs and represent the paradigmatic products of the revolution, carrying the "word" about the new opportunities: Computers, software and mobile phones today, automobiles and electrical appliances in the fourth, steel steam ships in the third, iron steam engines in the second and textile machinery in the first.

3. The infrastructures which are part of the revolution in terms of technology and whose impact is felt in shaping and extending the market boundaries for all industries: Internet today, roads and electricity in the fourth, the world transport network in the third (transcontinental railways and steamship routes and ports), national railways in the second and canals in the first.

A fourth category of induced branches may be added to encompass a set of industries that are not necessarily revolutionary in technological terms but that may be seen as indispensable to facilitate the maximum diffusion of the core industries. They may have existed before but they are modernised and take on a different role. Such was the case of the construction industry that made suburbanization possible during the mass production surge. The multiplication of housing at the edges of cities constantly expanded the market for automobiles and electrical appliances and created a whole technology system of standardised building materials and several other suppliers of goods and services for suburban construction and living. In the current world of globalised trade and internet shopping, a similar role is being played by the courier services -and all the other systems of transport of goods - that have experienced explosive growth and profound transformations to facilitate complex global and local logistics.

\section{The emergence of a techno-economic paradigm}

No matter how important and dynamic a set of new technologies may be, it only merits the term revolution if it has the power to bring about a transformation across the board. It is the techno-economic paradigm (TEP),

\footnotetext{
22 Perez (1983 and 1984)

23 For a discussion of the role of water wheels in the industrial revolution, see Tylecote (1992)
} 
evolving as the new technologies diffuse, that multiplies their impact across the economy and eventually also modifies the socio-institutional structures.

Such a meta-paradigm ${ }^{24}$ is the set of the most successful and profitable practices in terms of choice of inputs, methods and technologies and in terms of organisational structures, business models and strategies. Those mutually compatible principles and criteria develop in the process of using the new technologies, overcoming obstacles and finding more adequate procedures, routines and structures. The emerging heuristic routines and approaches are gradually internalized by engineers and managers, investors and bankers, sales and advertising people, entrepreneurs and consumers. In time, a shared logic is established; a new "common sense" is accepted for investment decisions as well as for consumer choice. The old ideas are unlearned and the new ones become "normal".

The extraordinarily efficient pyramidal structures with clearly defined roles and tasks that handled growth and innovation in the mass production paradigm of the 1950s are seen as bureaucratic dinosaurs next to the dynamic global networks digitally interconnected with multi-skilled personnel and high levels of autonomy of the flexible production paradigm of the current Information Technology revolution. The marvel of the cabled telephone for talking at a distance becomes a museum piece when consumers can normally expect wireless multipurpose devices for all communication, information and entertainment needs.

The construction of a techno-economic paradigm occurs simultaneously in three main areas of practice and perception:

1. In the dynamics of the relative cost structure of inputs to production where new low- and decreasing-cost elements appear and become the most attractive choice for profitable innovation and investment

2. In the perceived spaces for innovation, where the entrepreneurial opportunities are increasingly mapped for the further development of the new technologies or for using them advantageously in the existing sectors, and

3. In the organisational criteria and principles, where practice keeps showing the superior performance of particular methods and structures when it comes to taking advantage of the power of the new technologies for maximum efficiency and profits.

24 To avoid unpleasant repetitiveness, TEP and meta-paradigm will be used as synonyms of techno-economic paradigm. 
On all three areas, the emergence of the paradigm is a function of the rhythm of diffusion of the revolutionary products, technologies and infrastructures. At first the impact is localized and minor, with time it is widespread and all-encompassing. The changes occur in the economy and in the territory, in behaviours and in ideas. The paradigm and its new common sense criteria become ingrained and act as inductors and filters for the pursuit of technical, organisational and strategic innovations as well as for business and consumer decisions. The process is self-reinforced as the further propagation and adoption of the new technologies confirm in practice the wisdom of the shared principles

\section{The changes in the cost structure}

The new dynamics introduced in the relative cost structure is an important driver of the emergence of the new techno-economic paradigm (TEP). In fact, a crucial element in the articulation of a revolutionary constellation is the appearance of a key input ${ }^{25}$ that is (i) obviously cheap and getting cheaper, (ii) inexhaustible in the foreseeable future, (iii) all-pervasive in its applications and (iv) capable of increasing the power and decreasing the cost of capital and labour. ${ }^{26}$

Such was cheap water power for the mills and canals in the first revolution; cheap coal for the steam powered railways and mills of the second; cheap steel for the worldwide steamships, railways, the giant bridges and structures and the major chemical and electrical equipment of the third; cheap oil for the internal combustion engines of automobiles, trucks, airplanes and ships as well as for the production of electricity and, finally, cheap microprocessors for the computers and telecom equipment of the current fifth.

The general price profile is also radically modified by the growing cost advantage of the new infrastructure. This happens in two main ways: directly through decreasing prices (as operational volume decreases the unit cost of transport) and indirectly through increasing the market reach of users and therefore allowing greater economies of scale in production and distribution. So the preferred direction of innovation is already suggested by the relative cost profile of inputs and transport, which become a part of the meta-paradigm.

Wedgwood pottery could not go far without breaking on the backs of mules along uneven turnpike roads; it could reach the world going from river to canal and from canal to river and on to the wide seas.

25 Originally termed "key factor" in Perez (1983, 1984 and 1985)

26 Perez (1984) 


\section{The perception of opportunity spaces}

The second way in which the meta-paradigm signals the best direction for investment and innovation is by the perception of the profitable opportunity spaces. These are ever more clearly defined as the new technologies propagate and multiply. Such spaces are of two main types: those of the producers of the new technologies and those of the users.

At the core of the revolution are the basic scientific and engineering principles that opened the whole new universe of possibilities. The dynamism of innovation in those opportunity spaces is internally driven and the contributing industries are mutually-reinforced. However, their evolution is constantly creating new spaces for innovation in the rest of the economy due to the generic technologies of ample applicability that each revolution provides. The new infrastructures are the most obvious all-pervasive generic technologies; the others are the new sorts of materials and equipment that penetrate the operational context of every other industry.

In terms of infrastructures, the current role of Internet in the major reshaping of structures and behaviours in finance and trade needs no reminder. In the fourth surge, the networks of roads and electricity to the home made widespread suburban living possible.

Equipment such as the steam engine, in the second, liberated industry from the need to be near a source of water power. The individual electric motor, in the third, allowed industry to do away with the forest of belts and the simultaneous operation of all machines; it also allowed small scale powered industry.

In materials, the molecular "lego" trajectory of innovation in the petrochemical technology system opened a wider and wider range of application opportunities across the economy, from successive plastics for packaging or structures, through textile fibres and fertilizers to detergents and pharmaceuticals during the fourth surge.

\section{New organisational models}

Finally, the meta-paradigm incorporates the criteria for best organisational practice. As the new technologies transform work and consumption patterns, they also transform the way work and businesses are organised. Regular practice in the use of these technologies and in relating to the new conditions in the market contributes to the establishment of new principles of organisation that prove superior to the previous and become part of the new common sense for efficiency and effectiveness. 
The penny post, telegraph and national railways in the second surge changed, for instance, the structure of the banking industry from isolated local institutions to national networks of local branches. The railways themselves became very large business structures requiring what were then the most advanced organisational and logistics innovations for the management of complex systems.

Following Ford's example, the assembly line with Taylorist principles generalised in the fourth surge and deeply transformed the organization of fabricated products. The clear separation between blue and white collar workers, between the thinking and the executing, had consequences that went far beyond the factory. And so did the much greater productivity achieved with that organization. Ford's reduction of the work force and more than doubling the average wage together with his claim that cars would be cheap enough for his workers to buy were a foretaste of the social transformation to come.

In each case, the change in organisational and business logic becomes wide ranging and modifies business models and strategies so that the ones that are more compatible with the general logic of the paradigm prove to be more successful, become highly visible and are increasingly imitated. Thus the TEP is further enriched and the process is self-reinforced.

Table 3 gives a few of the most salient and general innovation principles that have characterized each of the successive techno-economic paradigms. ${ }^{27}$

27 By the fourth surge, the transmission of the full model with all its principles and practices had become the professional activity of hundreds of consultants in Scientific Management (Taylorism). In the current surge it has blossomed into a full-fledged economic sector and has been transforming deeply the contents of the MBA courses developed under the previous paradigm. 
Table 3. The five great surges of development and their techno-economic paradigms

\begin{tabular}{|c|c|}
\hline $\begin{array}{l}\text { Great surge of development } \\
\text { Core country }\end{array}$ & $\begin{array}{l}\text { Techno-economic paradigm } \\
\text { ‘Common-sense' innovation principles }\end{array}$ \\
\hline $\begin{array}{l}\text { FIRST: From } 1771 \\
\text { The 'Industrial Revolution' } \\
\text { Britain }\end{array}$ & $\begin{array}{l}\text { Factory production } \\
\text { Mechanization } \\
\text { Productivity/ time keeping and time saving } \\
\text { Fluidity of movement (as ideal for machines with water -power and } \\
\text { for transport through canals and other waterways) } \\
\text { Local networks }\end{array}$ \\
\hline $\begin{array}{l}\text { SECOND: From } 1829 \\
\text { Age of Steam and Railways } \\
\text { In Britain and spreading to } \\
\text { Continent and USA }\end{array}$ & $\begin{array}{l}\text { Economies of agglomeration/ Industrial cities/ National markets } \\
\text { Power centres with national networks } \\
\text { Scale as progress } \\
\text { Standard parts/machine -made machines } \\
\text { Energy where needed (steam) } \\
\text { Interdependent movement (of machines and of means of transport) }\end{array}$ \\
\hline $\begin{array}{l}\text { THIRD: From } 1875 \\
\text { Age of Steel, Electricity and } \\
\text { Heavy Engineering } \\
\text { USA and Germany overtaking } \\
\text { Britain }\end{array}$ & $\begin{array}{l}\text { Giant structures (steel) } \\
\text { Economies of scale of plant/ vertical integration } \\
\text { Distributed power for industry (electricity) } \\
\text { Science as a productive force } \\
\text { Worldwide networks and empires (including cartels) } \\
\text { Universal standardisation } \\
\text { Cost accounting for control and efficiency } \\
\text { Great scale for world market power/ 'small' is successful, if local }\end{array}$ \\
\hline $\begin{array}{l}\text { FOURTH: From } 1908 \\
\text { Age of Oil, the Automobile and } \\
\text { Mass Production } \\
\text { In USA and spreading to Europe }\end{array}$ & $\begin{array}{l}\text { Mass production/mass markets } \\
\text { Economies of scale (product and market volume)/ horizontal } \\
\text { integration } \\
\text { Standardisation of products } \\
\text { Energy intensity (oil based) } \\
\text { Synthetic materials } \\
\text { Functional specialisation/ hierarchical pyramids } \\
\text { Central isation/ metropolitan centres - suburbanisation } \\
\text { National powers, world agreements and confrontations }\end{array}$ \\
\hline $\begin{array}{l}\text { FIFTH: From } 1971 \\
\text { Age of Information and } \\
\text { Telecommunications } \\
\text { In USA, spreading to Europe and } \\
\text { Asia }\end{array}$ & $\begin{array}{l}\text { Information -intensity (microelectronics -based ICT) } \\
\text { Decentral ised integration/ network structures } \\
\text { Knowledge as capital / intangible value added } \\
\text { Heterogeneity, diversity, adaptability } \\
\text { Segmentation of markets/ proliferation of niches } \\
\text { Economies of scope and specialisation combined with scale } \\
\text { Globalisation/ interaction between the global and the local } \\
\text { Inward and outward cooperation/ clusters } \\
\text { Instant contact and action / instant global communic ations }\end{array}$ \\
\hline
\end{tabular}

Source: Based on Perez (2002) p. 18

A techno-economic paradigm is then the result of a complex collective learning process articulated in a dynamic mental model of the best economic, technological and organisational practice for the period in which a specific technological revolution is being adopted and assimilated by the economic and social system. Each TEP combines shared perceptions, shared practices and shared directions of change. Its adoption facilitates the achievement of the maximum efficiency and profitability and its diffusion provides a common understanding among the different agents that participate in the economy, from producers to consumers. 


\section{Diffusion, resistance and assimilation of successive techno-economic paradigms}

It is to be noted that some of the principles indicated in table 3 extend beyond the economy into the social and institutional. Suburbanisation -listed in the fourth- and globalisation -in the fifth- are two such instances.

In fact, the common sense principles of organisation for maximum efficiency and effectiveness embodied in the techno-economic paradigm gradually spread out of the business world and into government and other non profit institutions. The operations manuals and hierarchical structures of government ministries in the 1960s were fundamentally similar to those of a big mass production corporation. Yet, at present, these two sorts of institutions are very different. The changes that have been occurring in company structures and organisations since the irruption of the information revolution in the 1970s have radically changed them into what are now the flexible networked (increasingly global) corporations. But the processes of incorporating those more effective patterns into public institutions have been slow and are far from fully developed. This is not surprising. Organisational inertia is a well known phenomenon of human and social resistance to change. In the market economy, however, inertia is overcome by competition, which by showing the direction of success serves as a guide to best practice and as a survival threat to the laggards. That type of pressure and directionality is not present in most public institutions. Historically, then, these have lagged considerably (typically as much as twenty to thirty years) and have only imitated the paradigmatic principles developed in firms when forced to respond to political pressures for effectiveness.

Even in the economy, under the pressure of competition, the profound and wide-ranging changes made possible by each technological revolution and its techno-economic paradigm are not easily assimilated; they give rise to intense resistance and require bringing forth even stronger change-inducing mechanisms.

Eventually, the new TEP becomes the shared, established and unquestioned 'common sense' both in the economy and in the socio-institutional framework creating a clearly biased context in favour of the trajectories of the technologies of the revolution and their use across the economy. This adaptation generates externalities that operate as an inclusion-exclusion mechanism to encourage compatible innovations and discourage incompatible ones. This is an important part of the explanation of why change occurs by revolutions. Thus, techno-economic paradigms act as context shapers in favour of one revolution and -through over-adaptation- as hindrance and obstacle for the next. 
Hence, each great surge of development involves a turbulent process of diffusion and assimilation. The major incumbent industries are replaced as engines of growth by new emerging ones; the established technologies and the prevailing paradigm are made obsolete and transformed by the new ones; many of the working and management skills that had been successful in the past become outdated and inefficient demanding unlearning, learning and relearning processes. Such changes in the economy are very disturbing of the social status-quo and have each time accompanied the explosive growth of new wealth with strong polarising trends in the income distribution. These and other imbalances and tensions, including a major financial bubble and its collapse, result from the technological upheaval and end up creating conditions that require an equally deep transformation of the whole institutional framework. It is only when this is achieved and the enabling context is in place that the full wealth creating potential of each revolution can be deployed. ${ }^{28}$

\section{Putting it together: Regularities, continuities and discontinuities in technical change}

Within the neo-Schumpeterian lines of inquiry, innovation occupies an important space, including its dynamics, its clustering and interrelations. Studies of innovation have shown that the introduction of technical change is not random but path dependent and interdependent with other innovations clustered in systems, which are in turn interconnected in revolutions.

Although innovation is constant in the market economy, it is not always continuous. There are changes in rhythm that tend to follow a logistic curve and are influenced by the cycle of the technology system in which they are embedded. There are discontinuities often stimulated by the exhaustion of possibilities along a particular trajectory, where productivity and markets are approaching exhaustion.

The technology systems, grouped in a technological revolution, overlap and generate externalities and markets for each other, thus influencing the direction of further innovation.

Technological revolutions are clusters of interrelated technology systems that only merit the term 'revolution' because they extend far beyond the boundaries of the new industries they introduce. Such surges of change eventually transform the rest of the economy, elevate the expected level of

\footnotetext{
28 See Perez (2002) for an extended discussion of the processes of diffusion and assimilation of technological revolutions and TEPs as well as for the crucial role of the two complementary agents of innovation and growth -financial and production capital.
} 
productivity across the board, rejuvenate mature industries and open new innovation trajectories, not only within the new technologies, but also through their application to rejuvenate all the other industries and activities.

The vehicle of this wide-ranging transformation is the techno-economic paradigm, which is a best practice model gradually emerging from practice in order to make optimal use of the new innovative potential offered by each revolution. Each techno-economic paradigm serves as an envelope encompassing and shaping the trajectories of individual technologies. Its influence extends from the business sphere to institutions and society so that as the adoption of the new TEP advances along the diffusion curve of each technological revolution (or along each great surge of development), it gradually becomes the shared common sense for decision making in management, engineering, finance and trade. This new logic and its capacity to increase effectiveness and efficiency eventually also shape institutional and social organisations, expectations and behaviour.

This mutual adaptation of technology and society through the meta-paradigm enables reaping the maximum benefit from the wealth creating potential brought by each great surge. But, when this potential is exhausted and a new revolution begins to take shape, it acts as a powerful inertial force.

This understanding of the influence of technical change on long term economic growth is one of the key contributions of evolutionary economics to the understanding of macroeconomics as dynamic and historically shaped. It is no longer possible to ignore the technological revolution being diffused and its stage of deployment.

The level of abstraction at which growth processes are studied need not -and indeed should not- ignore the nature of the specific technologies being propagated. Neither suburbanization nor globalization would have been possible without mass production and the switch to the automobile as means of transport in the former or without transoceanic fibre optics, satellites and internet in the latter.

The concepts of long run equilibrium and continuous progress are profoundly questioned in favour of more complex processes of overcoming disequilibria originated in massive innovation, in internal differentiation within and between sectors, of creative destruction, assimilation, learning and unlearning successive technological spaces and best practice models and of reaching and overcoming maturity through successive surges of change. The changing rhythms of growth and the processes of structural change and productivity increase in the economy can now be understood as driven by technical change and as shaped by the diffusion of successive technological revolutions. 
Taken together, the micro, meso and macro view of how technologies evolve shows that it is possible to recognize the nature of technology, its forms of evolution and its interrelations as an object for social science analysis and as a way of embedding economic theory in the dynamics of its interaction with technology and institutions in a changing historical context.

Ignoring the potent role and influence of technical and institutional change in shaping the economy reduces the analytic capacity of economics. Incorporating them in a historically dynamic approach is an important task in order to enhance the explanatory and predictive power of economic science. Evolutionary economists and neo-Schumpeterians have pioneered in exploring and mapping that new territory.

\section{References}

Arthur, W. Brian (1988), 'Competing Technologies: An Overview', in Dosi et al. (eds.), pp. 590-607

Arocena, Rodrigo and Judith Sutz (2000) "Looking at national systems of innovation from the South", Industry and Innovation, Vol. 7, No. 1, pp. $55-75$

De Long, J. Bradford (2007) 'Creative Destruction's Reconstruction: Joseph Schumpeter Revisited', The Chronicle of Higher Education, December 7

Dosi, Giovanni (1982), 'Technical Paradigms and Technological Trajectories: A Suggested Interpretation of the Determinants of Technical Change', Research Policy, Vol. 2, No. 3, pp. 147-62

Dosi, Giovanni, Christopher Freeman, Richard Nelson, Gerald Silverberg and Luc Soete (eds.) (1988) Technical Change and Economic Theory, London and New York: Columbia University Press and Pinter

Enos, J.L. (1962) "Invention and innovation in the petroleum refining industry" in NBER The Rate and Direction of Inventive Activity, Princeton: Princeton University Press

Freeman, Christopher (1974), The Economics of Industrial Innovation, Harmondsworth, Middlesex: Penguin Books

- (1987), Technology Policy and Economic Performance: Lessons from Japan, London: Pinter

- (1992), The Economics of Hope, London: Pinter

- (1996) Long Wave Theory, ILCWE No. 69, Cheltenham: Elgar 
Grübler, Arnulf (1990) The Rise and Fall of Infrastructures, Heidelberg and new York: Physica-Verlag

Kondratiev, Nikolai D. (1935) 'The Long Waves in Economic Life', Review of Economic Statistics, No. 17, pp. 105-15

Kuhn, Thomas (1962:1970), The Structure of Scientific Revolutions, (2nd edition, enlarged), Chicago: University of Chicago Press

Louca, Francisco and Jan Reijnders (eds.) (1999) The Foundations of Long Wave Theory: Models and methodology, ILCWE No. 104, Cheltenham: Elgar.

Lundvall, Bengt Ake (1988), "Innovation as an interactive process: from user-producer interaction to the national system of innovation", Ch. 17 in Dosi et al. (eds.)

Nelson Richard and Sydney Winter (1977) 'In search of a useful theory of innovation' in Research Policy,

Malerba, Franco (2002) "Sectoral systems of innovation and production", Research Policy, Vol 31, No. 2, pp. 247-64

List, Frederick (1841), The National System of Political Economy, English edition 1904, London: Longman

Metcalfe, Stanley J. (2001) 'Restless capitalism: increasing returns and growth in enterprise economies,' in Industrial Structure and Innovation Dynamics, Edward Elgar

Perez, Carlota (1983), 'Structural Change and the Assimilation of New Technologies in the Economic and Social Systems', Futures, Vol. 15, No. 5, pp. 357-75

- (1984), "'Las Nuevas Tecnologías: Una Visión de Conjunto" (1986), in C. Ominami ed., La Tercera Revolución Industrial: Impactos Internacionales del Actual Viraje Tecnológico, Grupo Editor Latinoamericano, Buenos Aires, 1986, pp. 44-89. English version: The New Technologies: An Integrated View, The Other Canon and Tallinn University of Technology Working Papers in Technology Governance and Economic Dynamics, 19.

- (1985), 'Microelectronics, Long Waves and World Structural Change: New Perspectives for Developing Countries', World Development, Vol. 13, № 3, pp. 441-463

- (2002) Technological Revolutions and Financial Capital: the Dynamics of Bubbles and Golden Ages, Cheltenham: Elgar

- (2007) "Finance and technical change: a long-term view" in Hanusch, Horst and Andreas Pyka (eds.) Elgar companion to NeoSchumpeterian Economics, Cheltenham: Elgar, Ch. 49, pp. 775-99

Tylecote, Andrew (1992) The Long Wave in the World Economy, London: Routledge

Utterback, James M. and William J Abernathy. (1975), 'A Dynamic Model of Process and Product Innovation,' Omega, Vol. 3, No. 6, pp. 63956 
Reinert, Erik (2007) How Rich Countries Got Rich... and Why Poor Countries Stay Poor, New York: Carroll and Graf

Schumpeter, Joseph A. (1911:1961) The theory of Economic Development, New York: Oxford University Press (1939:1982), Business Cycles, 2 vols., Philadelphia: Porcupine Press

Serra, Antonio (1613) Breve trattato delle cause che possono far abbondare li regni d'oro e d'argento dove non sono miniere, Naples: Lazzaro Scorrigio

Wolf, J. (1912), Die Volkswirtschaft der Gegenwart und Zukunft, Leipzig: A. Deichert 


\section{Working Papers in Technology Governance and Economic Dynamics}

The Other Canon Foundation, Norway, and the Technology Governance program at Tallinn University of Technology (TUT), Estonia, have launched a new working papers series, entitled "Working Papers in Technology Governance and Economic Dynamics". In the context denoted by the title series, it will publish original research papers, both practical and theoretical, both narrative and analytical, in the area denoted by such concepts as uneven economic growth, techno-economic paradigms, the history and theory of economic policy, innovation strategies, and the public management of innovation, but also generally in the wider fields of industrial policy, development, technology, institutions, finance, public policy, and economic and financial history and theory.

The idea is to offer a venue for quickly presenting interesting papers scholarly articles, especially as preprints, lectures, essays in a form that may be developed further later on - in a high-quality, nicely formatted version, free of charge: all working papers are downloadable for free from http://hum.ttu.ee/tg as soon as they appear, and you may also order a free subscription by e-mail attachment directly from the same website.

The first nine working papers are already available from the website.

They are

1. Erik S. Reinert, Evolutionary Economics, Classical Development Economics, and the History of Economic Policy: A Plea for Theorizing by Inclusion.

2. Richard R. Nelson, Economic Development from the Perspective of Evolutionary Economic Theory.

3. Erik S. Reinert, Development and Social Goals: Balancing Aid and Development to Prevent 'Welfare Colonialism'.

4. Jan Kregel and Leonardo Burlamaqui, Finance, Competition, Instability, and Development Microfoundations and Financial Scaffolding of the Economy.

5. Erik S. Reinert, European Integration, Innovations and Uneven Economic Growth: Challenges and Problems of EU 2005.

6. Leonardo Burlamaqui, How Should Competition Policies and Intellectual Property Issues Interact in a Globalised World?

A Schumpeterian Perspective

7. Paolo Crestanello and Giuseppe Tattara, Connections and Competences in the Governance of the Value Chain. How Industrial Countries Keep their Competitive Power 
8. Sophus A. Reinert, Darwin and the Body Politic: Schäffle, Veblen, and the Shift of Biological Metaphor in Economics

9. Antonio Serra, Breve Trattato / A Short Treatise (1613) (available only in hardcopy and by request).

10. Joseph L. Love, The Latin American Contribution to CenterPeriphery Perspectives: History and Prospect

11. Ronald Dore, Shareholder capitalism comes to Japan

12. Per Högselius, Learning to Destroy. Case studies of creative destruction management in the new Europe

13. Gabriel Yoguel, Analía Erbes, Verónica Robert, and José Borello, Diffusion and appropriation of knowledge in different organizational structures

14. Erik S. Reinert and Rainer Kattel, European Eastern Enlargement as Europe's Attempted Economic Suicide?

15. Carlota Perez, Great Surges of development and alternative forms of globalization

16. Erik S. Reinert, lulie Aslaksen, Inger Marie G. Eira, Svein Mathiesen, Hugo Reinert \& Ellen Inga Turi, Adapting to Climate Change in Reindeer Herding: The Nation-State as Problem and Solution

17. Lawrence King, Patrick Hamm, The Governance Grenade: Mass Privatization, State Capacity and Economic Development in Postcommunist and Reforming Communist Societies

18. Reinert, Erik S., Yves Ekoué Amaïzo and Rainer Kattel. The Economics of Failed, Failing and Fragile States: Productive Structure as the Missing Link

19. Carlota Perez. The New Technologies: An Integrated View

20. Carlota Perez, Technological revolutions and techno-economic paradigms

The working paper series is edited by Rainer Kattel (kattel@staff.ttu.ee), Wolfgang Drechsler (drechsler@staff.ttu.ee), and Erik S. Reinert (reinert@staff.ttu.ee), who all of them will be happy to receive submissions, suggestions or referrals. 